\title{
Response of Young, Fruiting Sour Cherry Trees to One-time Trunk Injury at Harvest Date
}

\author{
Desmond R. Layne'and J.A. Flore ${ }^{2}$ \\ Department of Horticulture, Michigan State University, East Lansing MI 48824-1325 \\ Additional index words. girdling, mechanical harvest, phloem interruption, Prunus cerasus
}

\begin{abstract}
The influence of increasing levels of trunk damage on vegetative and reproductive capacity of 3- to 5-yearold 'Montmorency' sour cherry (Prunus cerasus L.) trees was determined for three seasons. Removal of or damage to bark up to halfway around the trunk circumference minimally affected growth and productivity. The total wound callus produced per tree was related to wound size. Wound repair was variable depending on the type or extent of injury. Removal of damaged bark greatly reduced wound repair. Girdling $75 \%$ or $100 \%$ of the trunk circumference resulted in no tree mortality at one site and $17 \%$ and $50 \%$ mortality, respectively, at another. Differentiated phloem in wound callus of trees with $100 \%$ bark removal and survival 4 years following injury indicated that vascular reconnection occurred across wounds.
\end{abstract}

Trunk injury to young, fruiting sour cherry trees from mechanical harvest, careless orchard implement use, freezing temperatures, animal feeding, insect boring, and disease invasion can reduce tree vigor, productivity, and orchard life. Brown et al. (1984) indicated that trunk or bark injury resulting from mechanical harvest is an important factor contributing to the rapid decline of sour cherry orchards. Damage that results from tree shaking can be attributed to operator or mechanical error, high cambial activity (low bark strength) at time of harvest (Fridley et al., 1970), or use of excessive force to remove immature fruit (Cargill et al., 1982). Bark maybe ruptured without disturbing the periderm and go unnoticed (Diener et al., 1968). In either case, vascular sap flow may be reduced. Trees with damaged bark are more susceptible to pathogens, since wounds provide a favorable environment for pathogen development (Cargill et al., 1982; Fridley et al., 1970).

Repair of wounds depends on wound size and severity, tree health and vigor, and the time of year at which injury occurs. Wounds incurred in the spring will heal more rapidly than wounds occurring in the late summer or fall (Crowdy, 1953; McQuilkin, 1950; Neeley, 1970; Wensley, 1966). Wounds heal most rapidly on vigorous trees (Chadwick and Nank, 1949; McQuilkin, 1950; Wensley, 1966).

Callus production in the wound zone is necessary for wound repair. This callus proliferation originates in the vascular rays in close proximity to the cut surface (Noel, 1968; Sharples and Gunnery, 1933; See, 1959). In some cases, vascular continuity can be reestablished as a result of vascular differentiation within the new callus tissue (Noel, 1968).

Since young sour cherry tree trunks are often damaged, the purpose of this study was to: 1) evaluate the responses of sour cherry trees to one-time trunk damage at commercial harvest and 2) determine threshold levels for one-time trunk injury that would be detrimental to vegetative and reproductive capacity and result in tree mortality of young, fruiting sour cherry trees.

\section{Materials and Methods}

All trunk damage experiments were conducted on young, fruiting sour cherry trees ('Montmoreney' on Mahaleb root-

Received for publication 7 Jan. 1991. We acknowledge the Michigan Agricultural Experiment Station for their support of this research and to F. Ewers for training in microtechnique. The cost of publishing this paper was defrayed in part by the payment of page charges. Under postal regulations, this paper therefore must be hereby marked advertisement solely to indicate this fact.

'Graduate Research Assistant.

${ }^{2}$ Professor. stock). Two sites were used: 1) the Horticultural Research Center, Michigan State Univ., East Lansing (HRC). Trees were planted in 1983 in a single east-west-oriented row at a 1-m spacing in Miami loam soil $(\mathrm{pH}=5.5-6.0)$ and were not pruned or supplementally irrigated. 2) Clarksville Horticultural Experiment Station, Clarksville, Mich. (CHES). Trees were planted in 1982 in north-south-oriented rows at spacings of $3.0 \times 6.0$ $\mathrm{m}$ and $3.0 \times 4.5 \mathrm{~m}$ on a Bixby sandy loam soil $(\mathrm{pH}=5.9$ 6.1). Trees at this site were trickle-irrigated, and pruning, fertilization, and other cultural practices were performed according to local standards. These trees were more than twice the size [based on trunk cross-sectional area (TCA) and tree height] and had a much higher fruit density than those at HRC in the season of injury. The trees at HRC were smaller than expected in a commercial orchard at the same age, while those at CHES were more typical of young, fruiting, commercial sour cherry trees in Michigan. Pesticides were applied according to commercial recommendations (Hewitt et al., 1987). All trunk injury treatments at both sites in 1986 and 1987 were imposed in the 2nd week of July, which is during the period of commercial harvest in Michigan.

Two preliminary experiments were conducted in 1986: 1) a bark removal experiment at HRC; and 2) a bark compression experiment at CHES. At HRC, 50 trees were selected based on uniformity. Trunk injury was imposed by removing a 5-cm-wide strip of bark encircling $0,25 \%, 50 \%, 75 \%$, or $100 \%$ of the trunk circumference (percent bark removal). There were 10 replicate trees used per treatment. Bark was cut to the xylem (between 15 and $20 \mathrm{~cm}$ above the graft union) with a sharp grafting knife and immediately peeled off. The exposed underlying tissue was left undisturbed. At CHES, mechanical harvest injury was simulated by bark compression using an instrument developed by the Agricultural Engineering Dept., Michigan State Univ. Clamping pressure and shear stress were imposed on a 14.3-mm-diameter circular section of bark (Brown et al., 1984) at a constant pressure of $0.38 \mathrm{MPa}$. Twenty-eight trees at the $3.0 \times 6.0-\mathrm{m}$ spacing were selected based on uniformity, and wound zones $0,10 \%, 20 \%$, or $40 \%$ around the trunk circumference were marked on the trunk. There were seven replicate trees used per treatment. Bark compressions were made using this instrument until the entire wound zone was filled in (bark was left intact). All trunk injury treatments in 1986 and 1987

Abbreviations: CHES, Clarksville Horticultural Experiment Station; HRC, Horticultural Research Center; TCA, trunk cross-sectional area. 
at CHES were imposed between 30 and $35 \mathrm{~cm}$ above the graft union, which is a normal position for mechanical harvester clamp attachment.

In 1987, the bark removal experiment (as described above at HRC in 1986) was repeated at CHES using 30 uniform trees at the $3.0 \times 4.5-\mathrm{m}$ spacing with six replicate trees per treatment. Eighteen additional trees at this spacing were selected for another experiment in which $50 \%$ of the bark was damaged as follows: 1) bark was removed using a grafting knife; 2) bark was compressed as described above and left intact; and 3) bark was compressed and then immediately removed using a grafting knife. There were six replicate trees per treatment.

Statistical calculations. Unless otherwise indicated, a randomized complete-block design was used for all studies and trees were blocked by TCA (Westwood and Roberts, 1970) before treatment imposition. Data were subjected to regression analysis or analysis of variance, as appropriate.

Nonstructural carbohydrates. Bark tissue was collected on 17 Nov. 1987 from trees at HRC that had $100 \%$ or $0 \%$ (control) of the strip removed. Five 16-mm-diameter disks were collected above and below the wound on trees that had $100 \%$ of the strip removed and five at the approximate wound height on the control trees. Five replicate trees representing each of the TCA size categories were sampled for each treatment. The protocol of Gucci (1988) was modified for bark tissue. Samples were freezedried and ground in a Wiley mill to pass through a 40-mesh screen. Four 100-mg subsamples of each sample were extracted four times each for $20 \mathrm{~min}$ with $2 \mathrm{ml}$ of $80 \%$ ethanol. The homogenates were centrifuged at $1500 \times \mathrm{g}$ for $5 \mathrm{~min}$ after each e x t r a c t i o n.

For determination of soluble sugars (sorbitol, fructose, glucose, inositol, and sucrose), the supernatants were transferred into 100-ml, round-bottom flasks and evaporated to dryness using a rotary vacuum evaporator in a water bath at 40C. The samples were converted into oximes (Roper et al., 1988) and derivatized to tri-methylsilyl ethers (Sweeley et al., 1963). Analyses were performed using a dual-column, temperature-programmed Varian 3700 gas chromatography (Varian Associates, Sunnyvale, Calif.) with a flame ionization detector and $3 \%$ OV-17 on $80 /$ 100 -mesh Chromosorb WHP in a $2 \mathrm{~mm} \times 2-\mathrm{m}$ glass column. Temperature was programmed from 150 to $250 \mathrm{C}$ at $5 \mathrm{C} / \mathrm{min}$. Quantity was calculated by peak area with a Spectra Physics SP41OO integrator (Spectra Physics, San Jose, Calif.) using internal standards. Two separate $1-\mu l$ injections were made for each sample and results were averaged.

Starch in the pellet was measured using the method of Roper et al. (1988) modified as follows: Samples incubated at 55C for $16 \mathrm{~h}$ with amyloglucosidase were assayed calorimetrically using glucose oxidase (Sigma Chemical Co., 1988). Absorbance at $440 \mathrm{~nm}$ was read with a Shimadzu UV-Vis 260 spectrophotometer (Shimadzu Corp., Kyoto, Japan).

Cold hardiness. Deep winter hardiness was evaluated for current-season shoots collected on 8 Feb. 1987 from trees at HRC according to methods of Bittenbender and Howell (1974). Four shoots were randomly selected from each of 20 trees representing all five treatments. Shoots were cut into $5-\mathrm{cm}-$ long sections and then subjected to a controlled temperature reduction in a freezing chamber. Samples were exposed to temperatures ranging from -20 to $-40 \mathrm{C}$ and then visually evaluated for xylem browning. $\mathrm{T}_{50}$ values, i.e., the temperature $\left({ }^{\circ} \mathrm{C}\right)$ required to kill half of the samples, were calculated for each treatment.

Anatomical examination. Five trees at HRC were sampled where callus tissue had completely filled in the wound zone during the season of injury. On 24 Mar. 1987, bark strips 7.0 $\mathrm{cm}$ long and $0.5 \mathrm{~cm}$ wide beginning just above the wound, then passing completely through the callus, and finally into the bark below were excised and fixed in formalin : acetic acid (FAA). Tissue was imbedded in paraffin, serial-sectioned at $13 \mu \mathrm{m}$, and stained with safranin and fast green. Sections were examined and photographed with a Zeiss (Oberkochen, Germany) Photomicroscope II at $\times 250$ magnification.

Reproductive and vegetative growth measurements. Wound repair was rated in Fall 1986 through 1989 when terminal growth had ceased. The amount of callus tissue present was visually rated as a percentage of the total wound surface.

TCA was calculated from the average of two perpendicular trunk diameters immediately above and below the wound, measured with a vernier caliper for all trees wounded in 1986 at HRC and CHES at the time of injury (11 July 1986) and in the late fall (15 Nov. 1986). Change in TCA, or trunk growth, was then calculated.

Current-season shoot growth was measured for eight and 10 terminal shoots per tree after terminal bud set for trees at HRC and CHES, respectively. Shoots were selected at a height of $\approx 2 \mathrm{~m}$ on the east side of trees.

Fruit density in the season following injury was determined as the number of fruit per square centimeter of limb crosssectional area at the base of two branches on opposite sides of the tree for all experimental trees at HRC and CHES on 2 June 1987. On 6 July 1987, fresh weights and percent soluble solids concentration (SSC) were determined for 25 fruits per tree for the $0 \%$ and $100 \%$ bark removal treatments at HRC. Fruit from all trees wounded in 1987 at CHES were harvested in 1988 and 1989, and yield was expressed as fruit weight (in kilograms) per tree.

\section{Results}

Bark removal experiment (HRC, 1986). In the season of injury, no relationship was observed between TCA or bark removal level and percentage of the total wound zone filled in with callus tissue $\left(r^{2}=0.16\right.$ and 0.06 , respectively). However, a linear relationship was observed between the amount of bark removed and the absolute amount of wound callus produced by the tree $\left(r^{2}=0.61\right)$. On average, trees filled in $58 \%$ of the wound zone with callus tissue. Shoot growth during the season of injury was not reduced by bark removal (mean value $=24$ $\mathrm{cm})$. Progression of healing for one tree with $100 \%$ bark removal is illustrated in Fig. 1. Trees with bark removed completely around the trunk had swollen bark above the wound, and this bark tissue accumulated more starch and sorbitol than bark from a similar position on a noninjured tree (Table 1). Fructose, glucose, inositol, and sucrose content of these tissues was not affected (mean values were 1.09, 1.25, 0.016, and 2.65 $\mathrm{mg} / 100 \mathrm{mg}$ tissue dry weight, respectively).

Deep winter cold hardiness at HRC was reduced from -29.0 to $-25.6 \mathrm{C}$ (significant at $\mathrm{P}=0.05$ ) in shoots from trees with $100 \%$ bark removal, but fruit density $\left(0.75 \mathrm{vs} .0 .93 / \mathrm{cm}^{2}\right)$ and fresh weight (3.37 vs. $3.61 \mathrm{~g})$ were not affected by bark removal. Fruit SSC at harvest was reduced, but not significantly ( $16.0 \%$ vs. $14.7 \%$ ), in trees with $100 \%$ bark removal. Phloem sieve tube cells were found in callus tissue that closely resembled those in bark tissue (Fig. 2). Four years after treatment, no tree death resulted from any of these degrees of bark removal.

Bark compression experiment (CHES, 1986). No significant bark 


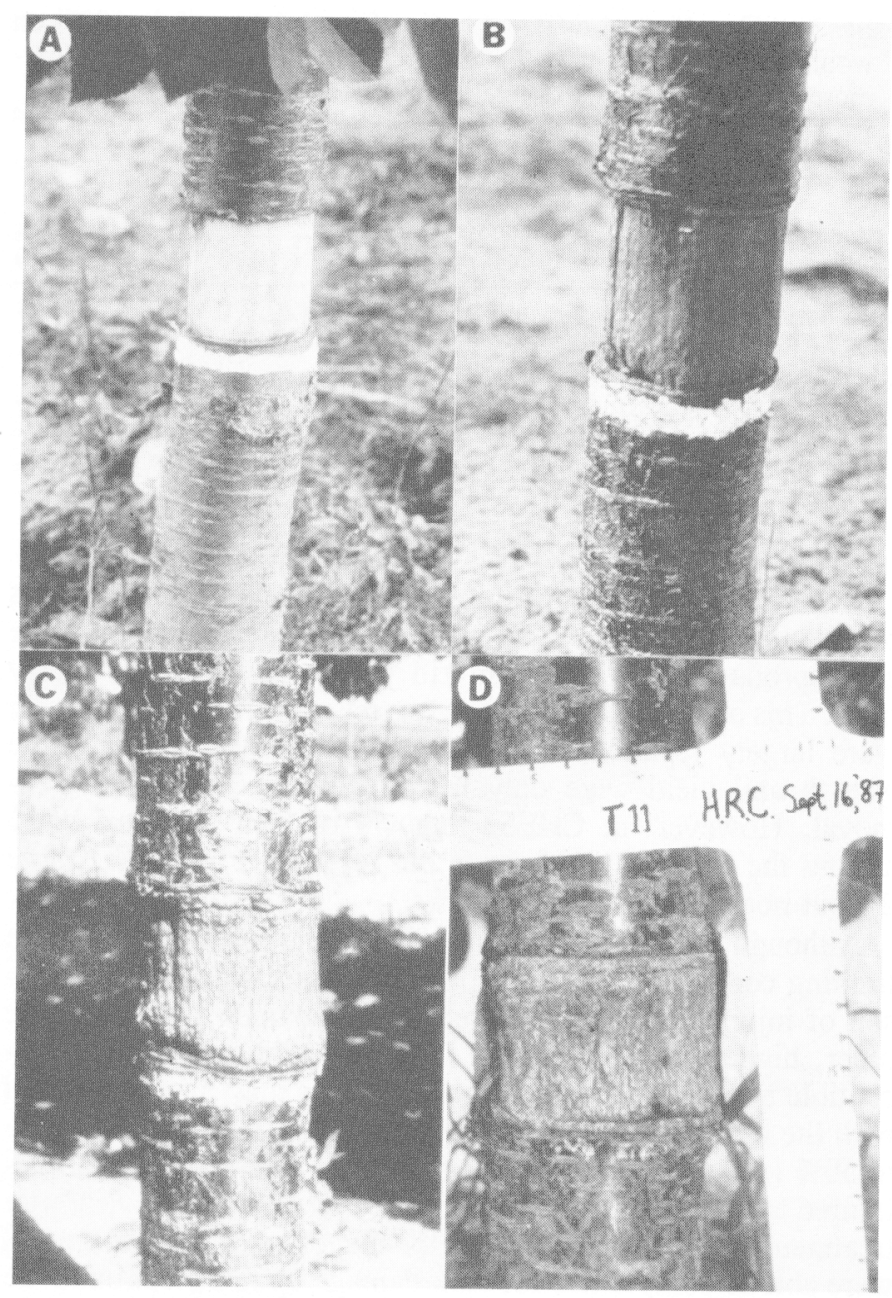

Fig. 1. Wound healing progression of one tree with $100 \%$ bark removal at HRC. Photographs were taken on: (A) 11 July 1986 (date of treatment); (B) 28 July 1986; (C) 16 Sept. 1986; and (D) 16 Sept. 1987.

Table 1. The effect of $100 \%$ bark removal (July 1986) on trunk growth and bark carbohydrate content of 4-year-old 'Montmorency'Mahaleb sour cherry trees at HRC. ${ }^{2}$

\begin{tabular}{lccc}
\hline $\begin{array}{c}\text { Bark removal } \\
(\%)\end{array}$ & $\begin{array}{c}\text { Trunk growth } \\
\text { July-Nov. 1986 } \\
\left(\mathrm{mm}^{2}\right)\end{array}$ & $\begin{array}{c}\text { Sorbitol } \\
\text { Nov. 1987 } \\
\left(\mathrm{mg} \cdot 100 \mathrm{mg}^{-1}\right)\end{array}$ & $\begin{array}{c}\text { Starch } \\
\text { Nov. 1987 } \\
\left(\mathrm{mg} \cdot 100 \mathrm{mg}^{-1}\right)\end{array}$ \\
\hline 0, Control & $462 \mathrm{~b}$ & $0.74 \mathrm{~b}$ & $1.03 \mathrm{ab}$ \\
100, Above wound & $761 \mathrm{a}$ & $1.18 \mathrm{a}$ & $1.21 \mathrm{a}$ \\
100, Below wound & $383 \mathrm{~b}$ & $0.84 \mathrm{~b}$ & $0.77 \mathrm{~b}$ \\
\hline
\end{tabular}

'Mean separation in columns by Duncan's multiple range test, $P=$ 0.05 .

swelling was observed above the wound in trees at the end of the season of injury. Fruit density the season following injury was not affected by the bark damage treatments (mean value $=0.9$ fruits/ $\mathrm{cm}^{2}$ ). Periderm was peeled back from wounds at the end of Summer 1987 and all wounds had been completely repaired. Photographs of one tree with $40 \%$ compression, taken at different dates following injury, are presented in Fig. $3 \mathrm{~b}$-d.

Bark removal experiment (CHES, 1987). In the season of injury, no relationship was observed between TCA or bark removal level and percentage of wound zone filled in with
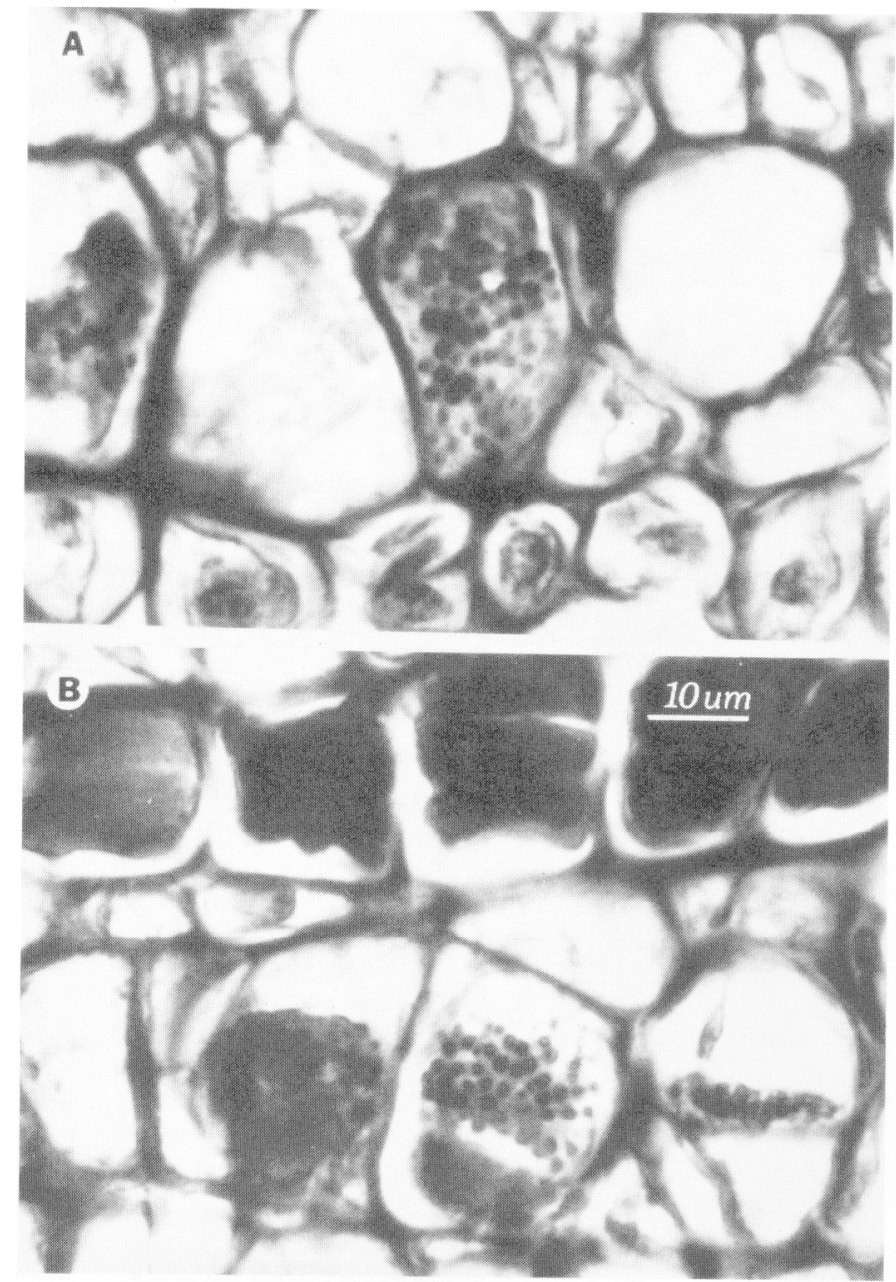

Fig. 2. Cross sections through sour cherry (A) noninjured bark with sieve plate and (B) callus tissue also illustrating presence of sieve plate and pores of phloem sieve tube cells $(\times 135)$. Tissue was collected at HRC on 24 Mar. 1987.

callus tissue $\left(r^{2}=0.29\right.$ and 0 , respectively). On average, trees filled in $21 \%$ of the wound zone with callus tissue. Annual shoot growth the season following injury (1988) was reduced at all levels of bark removal (Table 2). In 1988, fruit yield was highest in trees with $75 \%$ bark removal and lowest in trees with $100 \%$ bark removal. Differences in shoot growth and fruit yield between treated and control trees were negligible by 1989. In 1988, two of six trees with $100 \%$ bark removal were dead. By 1989, one tree with $75 \%$ and a total of three trees with $100 \%$ bark removal were dead. Dead trees were treated as missing plots for all data, except tree mortality, in the analysis.

Type of injury experiment (CHES, 1987). Wound repair was significantly affected by the type of bark injury imposed at harvest date. When crushed bark was left intact, more wound repair resulted than when bark was removed or crushed followed by bark removal (Table 3). Essentially no wound callus was produced in trees where crushed bark was removed. One such tree, typical for this experiment, is shown immediately following compression/removal in Fig. 3a. Note that both exposed trunk . tissue and peeled-off bark (below) were discolored, indicating injury. Annual shoot growth was highest in 1988 for trees in which crushed bark was removed. By 1989, shoot growth was 


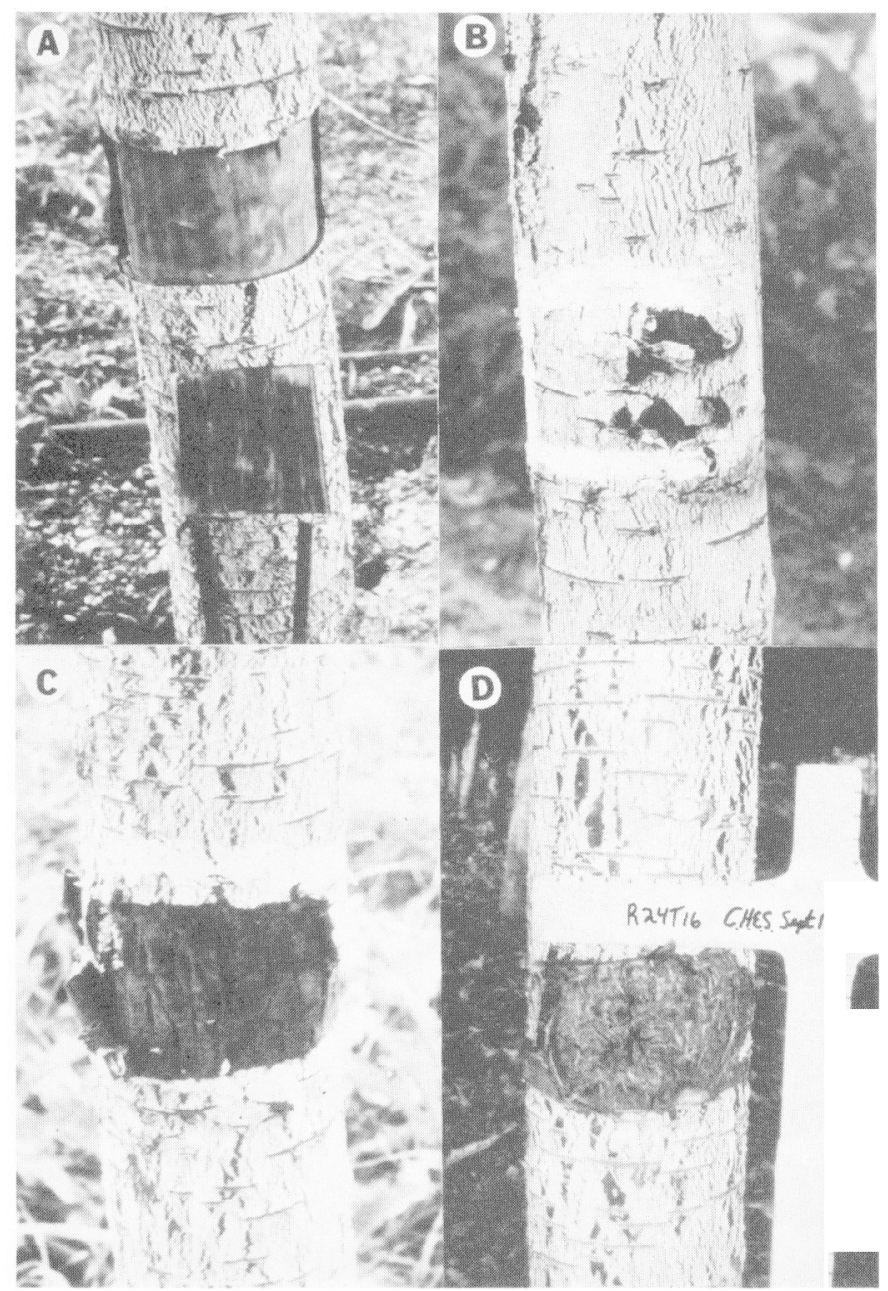

Fig. 3. Photographs of injury from bark compression instrument (A) of one tree at CHES immediately after removal of bark of which $50 \%$ of the trunk circumference had been compressed on 7 July 1987 (note discolored exposed wood and peeled-off bark below) and for another tree at CHES (B) immediately following bark compression $40 \%$ around the trunk circumference on 22 July 1986; (C) same as (B) on 5 Aug. 1986; (D) same as (B) on 17 Sept. 1987 (note that the periderm and outer bark have fallen off the wound).

Table 2. The effect of bark removal (July 1987) on shoot growth, fruit yield, and tree death of 5-year-old 'Montmorency'/Mahaleb sour cherry trees at CHES. ${ }^{\mathrm{z}}$

\begin{tabular}{|c|c|c|c|c|c|c|}
\hline \multirow{2}{*}{$\begin{array}{l}\text { Bark } \\
\text { removal } \\
(\%)\end{array}$} & \multicolumn{2}{|c|}{$\begin{array}{l}\text { Annual } \\
\text { shoot growth } \\
(\mathrm{cm})\end{array}$} & \multicolumn{2}{|c|}{$\begin{array}{c}\text { Fruit yield } \\
\text { (kg/tree) }\end{array}$} & \multicolumn{2}{|c|}{$\begin{array}{c}\text { Dead trees } \\
(\%)\end{array}$} \\
\hline & 1988 & 1989 & 1988 & 1989 & 1988 & 1989 \\
\hline 0 & 31.0 & 17.8 & 9.1 & 27.6 & 0 & 0 \\
\hline 25 & 25.3 & 20.9 & 9.1 & 31. & 0 & 0 \\
\hline 50 & 26.1 & 22.7 & 8.7 & 28.8 & 0 & 0 \\
\hline 75 & 17.3 & 17.5 & 13.6 & 30.3 & 0 & 17 \\
\hline 100 & 6.6 & 15.0 & 5.9 & 25.1 & 33 & 50 \\
\hline \multicolumn{7}{|c|}{ Significance } \\
\hline L & $0.29 * *$ & 0.01 & 0.04 & 0.02 & $0.14^{*}$ & $0.24^{* *}$ \\
\hline 0 & $0.31^{* *}$ & $0.07^{* *}$ & 0.04 & 0.21 & $0.25^{*}$ & $0.32^{* *}$ \\
\hline
\end{tabular}

${ }^{2}$ Coefficient of determination $\left(r^{2}\right)$ and significance at $P=0.05\left(^{*}\right)$ and $0.01\left({ }^{* *}\right)$ for the linear $(\mathrm{L})$ and quadratic $(\mathrm{Q})$ terms.

minimally reduced by any treatment. Fruit yield was not affected by these different types of trunk injury.
Table 3. The effect of different types of trunk injury (July 1987) on wound repair, shoot growth, and fruit yield of 5-year-old 'Montmorency'/Mahaleb sour cherry trees at CHES. ${ }^{2}$

\begin{tabular}{|c|c|c|c|c|c|}
\hline \multirow{2}{*}{$\begin{array}{l}\text { Trunk injury } \\
\text { treatment }\end{array}$} & \multirow{2}{*}{$\begin{array}{l}\text { Wound } \\
\text { repair } \\
(\%)\end{array}$} & \multicolumn{2}{|c|}{$\begin{array}{l}\text { Annual shoot } \\
\text { growth } \\
\text { (cm) }\end{array}$} & \multicolumn{2}{|c|}{$\begin{array}{c}\text { Fruit yield } \\
\text { (kg/tree) }\end{array}$} \\
\hline & & 1988 & 1989 & 1988 & 1989 \\
\hline $\begin{array}{l}50 \% \text { bark removal } \\
50 \% \text { of bark compressed } \\
50 \% \text { of bark }\end{array}$ & $\begin{array}{l}45 \mathrm{~b} \\
78 \mathrm{a}\end{array}$ & $\begin{array}{l}16.2 \mathrm{~b} \\
14.4 \mathrm{~b}\end{array}$ & $\begin{array}{l}20.7 \mathrm{~b} \\
22.2 \mathrm{ab}\end{array}$ & $\begin{array}{l}5.2 \\
5.0\end{array}$ & $\begin{array}{l}31.3 \\
28.1\end{array}$ \\
\hline compressed + removal & $6 \mathrm{c}$ & $19.4 \mathrm{a}$ & $24.3 \mathrm{a}$ & 4.4 & 30.7 \\
\hline
\end{tabular}

\section{Discussion}

One objective of this study was to determine threshold levels for one-time trunk injury that would be detrimental to vegetative and reproductive capacity and kill young, fruiting sour cherry trees. This objective was not met for trees at HRC, since wounds were largely repaired in the season of injury and vegetative growth and yield were only marginally affected by bark removal. However, at CHES, removal of bark $75 \%$ or $100 \%$ around the trunk circumference did result in tree death (Table 2 ), but not in the season of injury.

Although the younger trees at HRC were grown under more limiting conditions, wound repair was much greater in the season of injury than that observed for older trees at CHES. The older, higher-yielding trees at CHES possibly were more susceptible to stress, or tree age or initial size may have interacted with the healing response. None of the trees injured at the $\mathbf{2 5 \%}$ to $50 \%$ level died, and they were at least as productive as noninjured trees and only slightly less vigorous in the first year after treatment (Table 2). These results suggest that trees at CHES were able to compensate for bark damage up to $50 \%$ around the trunk circumference.

The other objective of this study was to evaluate responses of young, fruiting sour cherry trees to one-time trunk damage at commercial harvest. Since removal of nondamaged bark resulted in substantial wound callus production in trees at HRC, we hypothesized that removal of damaged bark might facilitate wound repair. The complete inhibition of wound callus production (Table 3) of trees at CHES implied, in fact, that removal of damaged bark was detrimental to wound repair. The discoloration of the underlying wood and the underside of the bark (Fig. 3a) indicated that cambial/xylem desiccation probably occurred, leading to reduced callus production because of vascular ray death (Noel, 1968; Sharples and Gunnery, 1933; See, 1959).

Scoring (making a single cut through the bark that encircles the trunk completely) and girdling (removal of a strip of bark, 2 to $5 \mathrm{~mm}$ wide, that encircles the trunk) are horticultural techniques that have been used to induce flowering and heavier cropping in some tree fruit crops (Westwood, 1978). Carbohydrates accumulated above the girdle in trees at HRC (Table 1), but no stimulation of floral initiation or increase in fruit density (and yield at CHES) was observed the following year at either site. The timing of girdling was probably too late in the season for this effect to be seen. However, girdling $75 \%$ around the trunk circumference did result in a $50 \%$ increase in yield for trees at CHES 1 year later, but this appears to have been fortuitous.

Some authors have indicated that wounds incurred in the spring (or early summer) heal more rapidly than wounds occurring in the late summer or fall (Crowdy, 1953; McQuilkin, 1950; Nee- 
Icy, 1970; Wensley, 1966). Because the vascular cambium was active at commercial harvest and since no insect or disease infestation was observed in any wounds at either site, wound repair conditions were probably ideal. Although all of the trees with $100 \%$ bark removal at CHES were of similar vigor (indicated by shoot growth and TCA) at the time of injury, half of them died over the next 2 years. The trees that died produced little or no wound callus, whereas those that survived produced a moderate amount. The absence of wound callus prevented vascular tissue regeneration, which may have resulted in root carbohydrate deprivation, as indicated by the significantly reduced foliation and shoot extension the following season (Table 2). At both HRC and CHES, trees in which vascular continuity was reestablished were only marginally affected in terms of growth and productivity.

This study indicates that the amount of wound callus produced is related to wound size in young, fruiting sour cherry trees. Trees at HRC that had bark removed completely around the trunk filled $71 \%$ of the wound zone with callus tissue during the season of injury. Remarkably, some trees had completely filled in this wound zone by the end of the summer. Trees within each site differed minimally in vigor, as estimated by trunk girth or vegetative shoot growth. Had there been large differences in tree vigor at a given site, a relationship between vigor and wound repair might have been observed, as has been noted by others (Chadwick and Nank, 1949; McQuilkin, 1950; Wensley, 1966). Martin and Sydnor (1987), however, noted poor relationships between wound closure rates and trunk caliper increases or twig extension in 12 tree species.

This study did not consider repeated injury occurring to the same tree as might occur in a mechanically harvested commercial orchard. The threshold for one-time trunk injury at harvest in young, fruiting sour cherry trees is quite high. Bark damage encircling up to $50 \%$ of the trunk circumference was not detrimental to trees in this study. Further experiments are needed to document the response of mature trees to annual damage as it relates to orchard decline.

\section{Literature Cited}

Bittenbender, H.C. and G.S. Howell, Jr. 1974. Adaptation of the Spearman-Karber method for estimating $\mathrm{T}_{50}$ of cold stressed flower buds. J. Amer. Soc. Hort. Sci. 99:187-190.

Brown, G. K., J.R. Frahm, L.J. Segerlind, and B.F. Cargill. 1984. Shaker damage to cherry bark-Causes and cures, p. 364-371. Proc. Intl. Symp. Fruit, Nut, \& Vegetable Harvesting Mechanization, Bet Dagan, Israel, 5-12 Oct. 1983. Amer. Soc. Agr. Eng. Publ. 5-84.
Cargill, B. F., G.K. Brown, and M.J. Bukovac. 1982. Factors affecting bark damage to cherry trees by harvesting machines. Michigan State Univ. Coop. Ext. Serv. Agr. Eng. Info. Ser. 471.

Chadwick, L.C. and E.E. Nank. 1949. Effects of certain pruning practices and wound dressings on callusing of tree wounds. Proc. Amer. Soc. Hort. Sci. 53:226-232.

Crowdv, S.H. 1953. Observations on the effect of growth stimulating compounds on the healing of wounds on apple trees. Ann. Applied Biol. 40:197-207.

Diener, R. G., J.H. Levin, and B.R. Tennes. 1968. Directional strength properties of cherry, apple and peach bark and the influence of limb mass and diameter on bark damage. Trans. Amer. Soc. Agr. Eng. 11:788-791.

Fridley, R. B., G.K. Brown, and P.A. Adrian. 1970. Strength characteristics of fruit tree bark. Hilgardia 40:205-223.

Gucci, R. 1988. The effect of fruit removal on leaf photosynthesis, water relations. and carbohydrate partitioning in sour cherry and plum. PhD Diss., Michigan State Univ., East Lansing (Diss. Abstr. DA8824850).

Hewitt, A. J., A.L. Jones, and J. Hull. 1987. Fruit spraying calendar. Michigan State Univ. Ext. Bul. E-154.

Martin, J.M. and T.D. Sydnor. 1987. Differences in wound closure rates in twelve tree species. HortScience 22:442-444.

McQuilkin, W.E. 1950. Effects of some growth regulators and dressings on the healing of tree wounds. J. For. 48:423-428.

Neeley, D. 1970. Healing of tree wounds. J. Amer. Soc. Hort. Sci. 95:536-540.

Noel, A.R.A. 1968. Callus formation and differentiation at an exposed cambial surface. Ann. Bot. 32:345-359.

Roper, T. R., J.D. Keller, W.H. Loescher, and C.R. Rem. 1988. Photosynthesis and carbohydrate partitioning in sweet cherry: Fruiting effects. Physiol. Plant. 72:42-47.

Sharples, A. and H. Gunnery. 1933. Callus formation in Hibiscus rosasinensis L. and Hevea brasiliensis Mull. Arg. Ann. Bet. 47:827839.

Sigma Chemical Co. 1988. Sigma diagnostics-Glucose procedure no. 510. Sigma Chemical Co., St. Louis.

See, K. 1959. Anatomical studies of bark regeneration following scoring. J. Arnold Arboretum 40:260-267.

Sweeley, C. C., R. Bentley, M. Makita, and W.W. Wells. 1963. Gasliquid chromatography of trimethylsilyl derivatives of sugars and related substances. J. Amer. Chem. Soc. 85:2497-2505.

Wensley, R.N. 1966. Rate of healing and its relation to canker of peach. Can. J. Plant Sci. 46:257-264.

Westwood, M.N. 1978. Temperate-zone pomology. W.H. Freeman \& Co., New York.

Westwood, M.N. and A.N. Roberts. 1970. The relationship between trunk cross-sectional area and weight of apple trees. J. Amer. Soc. Hort. Sci. 95:28-30. 